\title{
Kepemimpinan Orangtua dalam Mendidik Anak Melalui Unggah- ungguh Basa dan Basa Semu di Lingkungan Masyarakat
}

\author{
Kusno Effendi \\ Program Studi Bimbingan dan Konseling Universitas Ahmad Dahlan \\ J1. Pramuka No. 42, Sidikan, Umbulharjo, Yogyakarta, Indonesia \\ Email:kusnoeffendibk@gmail.com
}

\begin{abstract}
Educational leadership is the influence of an educational leader in educating children by moving, directing, motivating, and balancing to attain educational goals. This research included issues related to parental leadership, the quality of leadership of parents, leadership success of parents, parental leadership types, the parents' barriers in leadership to educate children and the use of unggah-ungguh basa and Basa Semu in educating children. The research method used qualitative research approach. There were 6 people taken by purposive sampling as the research subject. The technique of collecting data used an unstructured interview. To validate the data collection tools, it used triangulation techniques with the examination of the data source. Analysis and interpretation of the data were based on the criteria. The conclusion of the study: 1) Parental leadership to educate children using unggah ungguh basa and Basa Semu was less active, less qualified and did not succeed. 2) Parents were not active in providing educational leadership to children, 3) Parents are less qualified to educate leadership to children, 4) Parents were inactive, less qualified and did not succeed in educating albeit they understand unggah-ungguh basa and Basa Semu, 5) Leadership types of parents to educate children in unggah-ungguh basa in the village community of Gilangharjo, Pandak, Bantul is permissive type. The research can be used as a refernce in developing a curriculum based on cultural values, including local culture, which affects moral development of children.
\end{abstract}

Keywords: parental leadership, parenting, unggah-ungguh basa, basa semu

Kepemimpinan pendidikan adalah pengaruh seorang pemimpin pendidikan dalam mendidik anak dengan cara menggerakkan, mengarahkan, memotivasi, dan menyeimbangkan untuk mencapai tujuan pendidikan. Penelitian ini mencakup masalah-masalah terkait kepemimpinan orangtua dalam mendidik anak, kualitas kepemimpinan orangtua dalam mendidik anak, keberhasilan kepemimpinan orangtua dalam mendidik anak, tipe kepemimpinan orangtua mendidik anak, hambatan-hambatan orangtua dalam kepemimpinan mendidik anak dan penggunaan unggah ungguh basa dan Basa Semu dalam mendidik anak. Metode penelitian menggunakan pendekatan penelitian kualitatif. Jumlah subjek penelitian sebanyak 6 orang yang diambil dengan purposive sampling. Teknik pengumpulan data menggunakan wawancara tidak terstruktur. Validitas alat pengumpulan data menggunakan teknik triangulasi dengan pemeriksaan sumber data. Analisis dan interpretasi data berpedoman pada kriteria. Kesimpulan hasil penelitian: 1) Kepemimpinan orangtua mendidik anak dalam unggah-ungguh basa dan Basa Semu kurang aktif, kurang berkualitas dan tidak berhasil. 2) Orangtua tidak aktif memberikan didikan kepemimpinan kepada anak, 3) Orangtua kurang berkualitas mendidik kepemimpinan anak, 4) Orangtua tidak aktif, kurang berkualitas dan tidak berhasil dalam mendidik meskipun memahami unggah-ungguh basa dan Basa Semu, dan 5) Tipe kepemimpinan orangtua mendidik anak dalam unggah-ungguh basa di lingkungan masyarakat desa Gilangharjo, Pandak, Bantul adalah tipe permisif. Peneilitian ini dapat dijadikan panduan dalam mengembangkan kurikulum berbasis pada nilai-nilai budaya termasuk budaya lokal, yang berdampak pada perkembangan moral anak

Kata kunci: kepemimpinan orang tua, pendidikan anak, unggah-ungguh basa, basa semu

\section{Pendahuluan}

Keluarga merupakan lembaga masyarakat yang paling kecil, dipimpin oleh seorang ayah. Keberadaan keluarga sebagai lembaga masyarakat kecil, mempunyai peranan yang besar dan penting bagi pertumbuhan dan perkembangan anak. Demikian pentingnya keluarga bagi anak-anak mengingat mereka mendapatkan pendidikan pertama dan utama dari kedua orangtuanya. Pendidikan orangtua kepada anak dengan proses mengajar, membimbing dan melatih, merupakan 
penanaman modal utama bagi perkembangan anak selanjutnya. Salah satu isi pendidikan orangtua kepada anak adalah pendidikan bahasa.

Bahasa merupakan alat komunikasi antara manusia satu dengan yang lain untuk mengekspresikan pikiran, perasaan dan kemauan. Bahasa merupakan pengetahuan abstrak yang dimiliki manusia pada semua budaya, dan digunakan sebagai alat komunikasi yang santun. Bahasa dapat menjadi salah satu indikator rusaknya masyarakat. Indikator itu adalah keadaan masyarakat yang sudah tidak beretika dalam berbahasa. Anak-anak sudah tidak mempunyai tatakrama atau unggah-ungguh basa ketika berbicara kepada orang yang lebih tua dan dihormati. Tanda-tanda kehancuran suatu masyarakat, ditunjukkan oleh beberapa gejala atau indikator tertentu dan salah satunya adalah bahasa.

"Tanda-tanda kehancuran suatu masyarakat, dapat dilihat dari beberapa gejala antara lain: 1) Meningkatnya kekerasan di kalangan remaja, 2), Ketidakjujuran yang membudaya, 3) Semakin rendah rasa tidak hormat oleh kaum muda kepada orang tua, guru, dan figur pemimpin, 4) Meningkatnya kecurigaan dan kebencian, 5) Penggunaan bahasa yang memburuk, 6) Penurunan etos kerja, 7) Menurunnya rasa tanggung jawab sebagai individu dan warga negara, 8) Meningginya perilaku merusak diri, dan 9) Semakin kaburnya pedoman moral".

Keluarga Jawa adalah salah satu masyarakat terkecil dari lembaga masyarakat di Indonesia dengan bahasa yang khas, ialah Basa Jawa. Bahasa Jawa memiliki keunikan tersendiri, utamanya memiliki tingkatan-tingkatan atau unggah-ungguh basa bagi pemakai dan penggunaannya dengan memperhatikan umur, jabatan, pangkat, dan keturunan. Bahasa Jawa diklasifikasikan berdasarkan tatakrama atau unggah-ungguh basa yang berlaku di lingkungan masyarakat suku Jawa.

Di samping unggah-ungguh basa sebagai ciri khas bahasa Jawa, keunikan lain adalah Basa Seтu. Basa Semu adalah suatu cara untuk mengekspresikan pikiran perasaan dan kemauan seseorang, dengan menggunakan simbol atau lambang. Di lingkungan masyarakat Jawa, komunikasi menggunakan Basa Semu termasuk sanépan dan pepindhan, merupakan cara yang lebih halus dan tersamar. Kehalusan budi orang Jawa terletak pada kemampuan mereka menggunakan
Basa Semu dalam berkomunikasi dengan orang lain.

Peneliti telah mewawancarai sepuluh anak usia Sekolah Lanjutan Pertama dan Menengah pada bulan November 2010 di dusun Krekah, Tegal Lurung, Kauman dan Jodog Desa Gilangharjo Pandak Bantul menunjukkan bahwa mereka kurang mampu dalam menggunakan unggahungguh basa dan Basa Semu. Ketidakmampuan mereka mencakup aspek fonologi, semantik, sintaksis dan pragmatik. Salah satu faktor yang mempengaruhi kekurangmampuan anak dalam berbicara Jawa sesuai unggah-ungguh basa dan Basa Semu dengan empat aspek tersebut adalah kepemimpinan orangtua dalam mendidik bahasa tersebut.

Berdasarkan dari apa yang telah dipaparkan sebelumnya menjadi sebuah pertanyaan mengenai 1) proses kepemimpinan orangtua mendidik anak dalam unggah-ungguh basa dan Basa Semu, 2) Proses aktifitas kepemimpinan orangtua mendidik anak belajar dan berbicara unggah-ungguh basa dan Basa Semu, 3) kualitas kepemimpinan orangtua mendidik anak belajar dan berbicara unggahungguh basa dan Basa Sетu , 4) tipe-tipe kepemimpinan orang tua mendidik anak belajar dan berbicara unggah-ungguh basa dan Basa Semu, dan 5) Hambatan-hambatan apa yang dihadapi kepemimpinan orangtua mendidik anak belajar dan berbicara unggah-ungguh basa dan Basa Semu.

\section{Pendidikan}

\section{Kajian Literatur}

Pendidikan merupakan proses penanaman nilai melalui pengajaran, bimbingan dan pelatihan oleh orangtua, guru atau orang lain yang kompeten kepada anak. Nilai-nilai agama dan budaya, merupakan isi pendidikan. Penanaman nilai agama dan budaya yang paling utama dan pertama adalah orangtua di keluarga. Pada Undang-Undang Republik Indonesia No. 2 Tahun 1989 tentang Pendidikan Nasional, Bab IV, pasal 10, ayat 4, dinyatakan

"Pendidikan keluarga merupakan salah satu bagian dari jalur pendidikan luar sekolah yang diselenggarakan dalam keluarga, dan yang memberikan keyakinan agama, nilai budaya, nilai moral dan ketrampilan". 
KEPEMIMPINAN ORANG TUA, PENDIDIKAN ANAK, UNGGAH-UNGGUH BASA

Orangtua dengan menguasai nilai-nilai agama dan budaya, diharapkan kompeten dalam menanamkan nilai-nilai tersebut kepada anak.

“... bentuk, dan isi serta cara-cara pendidikan keluarga, mempengaruhi pertumbuhan dan perkembangan watak, budi pekerti dan kepribadian tiap-tiap anak".

\section{Peranan Dan Tanggung Jawab Pendidikan}

Bagi orang tua, tanggung jawab mendidik anak seperti mengasah sebuah pisau, harus dilakukan secara hati-hati tetapi terus-menerus sampai mencapai ketajamannya. Mendidik anak adalah proses produksi yang penuh dengan hal-hal detail, memerlukan ketekunan dan kesabaran, namun kadang-kadang diperlukan sebuah ketegasan, penuh kedisiplinan. Beberapa prinsip dalam mendidik anak sebagai ujud pertanggungjawaban orang tua, dikenal lima (5) $-\mathrm{T}$.

\begin{abstract}
"Banyak orang membaca dan mempelajari prinsip-prinsip parenting sederhana untuk dijadikan pedoman dalam mendidik anak, namun karena sangat banayak konsep dan metode yang dipelajari, sulit untuk dapat dilaksanakan oleh para orangtua. Ada 5-T dalam mendidik anak ... adalah sebuah prinsip sederhana yang dapat dapat dilaksanakan dalam mendidik anak".
\end{abstract}

$\mathrm{T}$, pertama adalah Time atau waktu, maksudnya adalah waktu bersama yang berkualitas. Orangtua dalam menanamkan nilai agama dan budaya, memerlukan waktu yang tepat dan perlu keterlibatan bersama terutama ketika anak masih kecil. $\mathrm{T}$, ke dua adalah Telling maksudnya, memberitahu. Orang tua mendidik anak adalah tindakan memberitahu. Ayah atau ibu mengatakan cinta, senang, setuju, bahkan melarang sesuatu agar tidak dilakukan anak, lewat ucapan atau pernyataan. Orangtua mendidik, mengajar, melatih, lewat ucapan dan pemberitahuan. T, ke tiga ialah Teaching, diartikan sebagai mengajar dan membimbing. Orang tua bukan saja harus menanamkan nilai-nilia hidup dan budi pekerti, tetapi juga mengajarkan cara melakukannya. Ajarkan nilai-nilai budaya dan agama, sampai anak mengerti dan melakukan. $\mathrm{T}$, ke empat adalah training, artinya tanggung jawab orang tua melatih anak-anak untuk mendapatkan sejumlah ketrampilan hidup. Latihan-latihan dimulai dari yang paling sederhana misal, mencuci piring, membersihkan kamar tidur, sampai pada latihan yang bersifat mental, umpamanya tanggung jawab, toleransi, sabar, taat aturan, disiplin diri. T, ke lima adalah together, kebersamaan. Maksudnya, aktivitas orang tua dalam pembimbingan, pengajaran, dan pelatihan anak, memerlukan waktu dalam kebersamaan dengan mereka.

\section{Tujuan pendidikan}

Pada Undang-Undang Republik Indonesia No. 20 Tahun 2003 Tentang Sistem Pendidikan Nasional, Bab IV, pasal tujuh ayat dua, dengan tegas menyatakan bahwa setiap orang tua berkewajiban memberikan pendidikan dasar kepada anak sama dengan tujuan pendidikan formal. Hal ini tercantum pada Bagian Keenam, pasal 27 ayat satu, dua dan tiga Undang-Undang Republik Indonesia No. 20 Tahun 2003 tentang Sistem Pendidikan Nasional.

1) Kegiatan pendidikan informal yang dilakukan oleh keluarga dan lingkungan berbentuk kegiatan belajar secara mandiri, 2) Hasil pendidikan sebagaimana dimaksud pada ayat 1 diakui sama dengan pendidikan formal dan non-formal setelah peserta didik lulus ujian sesuai dengan standart nasional pendidikan, 3) Ketentuan mengenai pengakuan hasil pendidikan informal sebagaimana dimaksud pada ayat 2 diatur lebih lanjut dengan peraturan pemerintah.

Maksud ayat 1, 2, dan ayat 3 tersebut, bahwa pendidikan informal yang dilakukan keluarga, merupakan upaya yang dilakukan untuk mewujudkan terealisirnya tujuan pendidikan nasional. Seperti yang di ungkapkan Tafsir, (2005: 64) bahwa:

“...keluarga berkewajiban mendidik anggotaanggotanya, ialah agar anak mampu berkembang secara maksimal, meliputi seluruh aspek perkembangan, yaitu jasmani, akal dan rohani”.

\section{Kepemimpinan pendidikan}

Keberhasilan pendidikan sangat erat dengan aktifitas-aktifitas pendidikan yang digerakkan, di arahkan, dikoordinir dan dikontrol oleh pemimpin pendidikan. Salah satu konsep kepemimpinan pendidikan adalah upaya menggerakkan aktifitas pendidikan yang di arahkan sesuai dengan ramburambu yang telah ditetapkan agar tujuan pendidikan dapat tercapai secara efisien dan efektif. Suhardan, 
(2011: 126)

kepemimpinan:

mengemukakan mengenai

Kepemimpinan pendidikan merupakan kemampuan untuk menggerakkan pelaksanaan pendidikan, sehingga tujuan pendidikan yang telah ditetapkan dapat tercapai secara efisien dan effektif.

Orangtua dan guru kelas sebagai pemimpin pendidikan, berada di garis paling depan dalam memberikan keteladanan, motivasi, menggerakkan, mengarahkan dan mengontrol aktifitas belajar anak. Orangtua dan guru kelas adalah seorang pemimpin yang mampu mempengaruhi anak dalam belajar untuk mencapai tujuan pendidikan yang telah ditentukan. Seorang pemimpin pendidikan mampu menggerakkan, mengarahkan, memotivasi dan menyeimbangkan aktifitas belajar anak dan mampu menggunakan waktu secara efektif apabila mempunyai kepemimpinan pendidikan yang baik. Hal tersebut sesuai dengan pendapat Wahab \& Umiarso, (2011: 114).

"Kepemimpinan pendidikan adalah pemimpin pada satu lembaga satuan pendidikan, dan tanpa kehadiran kepemimpinan pendidikan, proses pendidikan termasuk pembelajaran tidak akan berjalan efektif".

\section{Tipe-tipe kepemimpinan pendidikan}

Tipe atau type adalah ciri-ciri yang melekat pada diri seseorang. Sifat-sifat yang melekat sebagai ciri individu, yang dapat berfungsi sebagai kriteria pengklasifikasian menjadi kelompokkelompok tertentu. Tipe kepemimpinan merupakan cerminan dan proyeksi diri dari sikap, sifat, kebiasaan, pola berfikir, perasaan dan tingkahlaku dari pemimpin. Salah satu indikator tipe kepemimpinan seseorang dilihat dari kemampuan menempatkan anak pada posisi yang benar.

Sejumlah tipe-tipe kepemimpinan dari seorang pemimpin, menurut Wahab dan Umiarso, (2011: 95-96) antara lain kepemimpinan otokratis, demokratis dan permisif, “...tipe-tipe kepemimpinan dibagi menjadi tiga bagian, yaitu otokratis, demokratis, permisif'

\section{Tipe kepemimpinan otoriter}

Tipe kepemimpinan otoriter atau kepemimpinan authoritarian, adalah kepemimpinan diktator terhadap anak. Tipe kepemimpinan ini, anak wajib mengikuti dan menjalankan perintah serta tidak boleh membantah atau memberi saran. Pemimpin harus patuh dan setia kepada pemimpin secara mutlak. Tipe kepemimpinan otoriter tidak menghendaki musyawarah, bahkan rapat tidak pernah diadakan.

\section{Tipe kepemimpinan demokratis}

Aktifitas-aktifitas yang dilakukan oleh pemimpin dengan tipe kepemimpinan ini, selalu berpijak pada kebutuhan dan kemampuan anak. Gambaran seorang pemimpin dengan kepemimpinan demokratis, adalah pemimpin dalam tugas, bersedia menerima dan mengharapkan pendapat-pendapat atau saran-saran dari anak. Kritik yang membangun dari anak, diterima sebagai umpan balik dan bahan pertimbangan tindakan selanjutnya.

\section{Tipe kepemimpinan permisif (bebas terpimpin)}

Tipe kepemimpinan permisif (bebas terpimpin), kurang dapat memberikan kepemimpinan kepada anak. Tipe ini menunjukkan kepemimpinannya dengan membiarkan anak berbuat dan bertindak semaunya. Pemimpin sama sekali tidak mengontrol dan mengoreksi tingkahlaku, tugas-tugas yang harus dikerjakan anak. Pemimpin tidak pernah menggerakkan, mengarahkan, memotivasi, menyelaraskan anak untuk mencapai tujuan.

\section{Pendidikan bahasa Jawa}

Bahasa Jawa adalah sistem lambang bunyi yang digunakan oleh masyarakat suku Jawa untuk berkomunikasi antara orang satu dengan yang lain. Maksud kata Jawa dalam bahasa Jawa, menunjuk pada orang dengan bahasanya sebagai salah satu kekayaan budaya. Seperti yang di ungkapkan Susesena, (2003: 11) bahwa yang disebut orang Jawa adalah orang yang bahasa ibunya adalah bahasa Jawa. Orang Jawa adalah pendudukan asli bagian tengah dan timur pulau Jawa yang berbahasa Jawa.

\section{Bahasa Jawa: budaya yang harus dilestarikan}

Bahasa Jawa pantas dilestarikan khususnya oleh masyarakat Jawa, mengingat bahasa Jawa merupakan salah satu kekayaan budaya Jawa. Bahasa Jawa memiliki ciri-ciri khas yang tidak dimiliki oleh bahasa lain misalnya etika, sopansantun berbicara atau unggah-ungguh basa. Di daerah Surakarta dan Daerah Istimewa Yogyakarta, dikenal prinsip othak-athik yang artinya di olah dan 
KEPEMIMPINAN ORANG TUA, PENDIDIKAN ANAK, UNGGAH-UNGGUH BASA

dianalisis, Basa Semu yaitu cara untuk mengekspresikan pikiran, perasaan dan kemauan seseorang kepada orang lain, menggunakan kode, lambang atau isyarat tertentu dan titèn yang berarti teliti, Nitèni adalah mengingat. Ciri-ciri kehidupan bersama, berdasarkan kultur Jawa diklasifikasikan menjadi tiga prinsip, Menurut Endraswara, (2003: 12) “... menunjukkan tiga ciri-ciri utama budaya Jawa: “ a) Othak-athik mathuk (O-A-M), b) Wong Jawa nggone semu, c) Prinsip cocok lan ngelmu titen."

\section{Pembelajaran bahasa Jawa}

Seorang anak dari keluarga Jawa dapat berbicara bahasa Jawa dengan baik dan lancar, melalui proses pembelajaran dan latihan. Belajar dan berlatih bahasa Jawa, dimulai semenjak kanakkanak. Peran keluarga terutama ayah dan ibu dalam pembelajaran bahasa Jawa bagi anaknya, sangat besar. Anak-anak lancar atau tidak dalam berbicara bahasa Jawa, kemungkinan bersumber dari orangtua, mengingat orangtua berperan mengajarkan bahasa kepada anak. Cara pertama anak belajar berbicara adalah dengan meniru bahasa orang lain. Kedua, orangtua menjadi teladan bagi anak dalam meniru gaya bicara, aksen, tatakrama atau unggah-ungguh berbicara.

\section{Tata aturan unggah-ungguh basa}

Unggah-ungguh basa atau tata krama, merupakan tingkat tutur, tata cara atau tata aturan yang bersifat turun temurun. Unggah-ungguh basa, berkembang dalam budaya masyarakat yang mengatur pergaulan antara individu satu dengan yang lain. Unggah-ungguh basa mengandung nilai yang berlaku pada suatu daerah tertentu, namun secara umum suku Jawa utamanya di Jawa Tengah, mempunyai aturan dan pedoman yang sama, Menurut Purwadi, (2005:43-44).

" Unggah-ungguh basa jawa kinarya ngemu suraos ingkang wigatos. Amargi basa menika dados piranti ing salebeting pasrawungan ... Budi pekerti basa jawi yang berupa unggahungguh ini, ujudnya dapat berbentuk: (1) Atur kasugengan, (2) Tata krama sesrawungan, (3) Sopan santun basa, (4) Unggah-ungguh marang sing luwih tuwa, (5) Pasrawungan bebrayan luhur, (6) Asung pawarta wigati, dan (7) Jiwa kamardikan."

Unggah-ungguh basa, berbeda-beda aplikasinya. Perbedaan itu tampak pada tatanan basa yang digunakan dan gerakan-gerakan tubuh yang harus ditunjukkan. Berdasarkan gerakan tubuh dan tatanan basa, dapat diketahui dengan siapa seseorang berbicara. Inti unggah-ungguh adalah memberikan rasa hormat kepada orang lain. Hal tersebut diperkuat seperti pendapat Endraswara, (2003: 125)

"Unggah-ungguh itu bukanlah suatu perilaku yang sifatnya sepihak dari bawah ke atas, melainkan bersifat interaksi, dan tertip yang mantap berlandaskan hukum dan kesadaran moral".

\section{Klasifikasi unggah-ungguh basa}

Basa Jawa, dikenal sebagai salah satu bahasa yang rumit dengan unggah-ungguh basa. Kerumitan itu terletak pada tata aturan yang berjenjang berdasarkan perbedaan kedudukan, jabatan, pangkat, umur dan yang lain. Rumitnya unggah-ungguh basa atau tatakrama Basa Jawa adalah wajar sehingga saat ini, jarang digunakan untuk komunikasi sehari-hari. Terutama bagi generasi muda, mereka lebih sering menggunakan Bahasa Indonesia dibandingkan Basa Jawa. Di lingkungan masyarakat Jawa, khususnya Yogyakarta dan Surakarta, unggah-ungguh basa Jawa, dibedakan menjadi tiga klasifikasi: (1) Basa Ngoko, (2) Basa Madya, dan (3) Basa Krama.

1. Basa Ngoko, termasuk bahasa kasar dalam unggah-ungguh basa. Pada umumnya bahasa ini digunakan: a) antara anak satu kepada yang lain yang seusia, b) berbicara antara dua orang atau lebih yang sudah akrab, c) orang yang lebih tua kepada yang lebih muda.Bahasa ngoko dibagi menjadi dua macam ialah (1) Ngoko Lugu dan (2) Ngoko Andhap.

2. Basa Madya, mempunyai unggah-ungguh basa yang lebih rumit, karena dibagi menjadi beberapa tingkatan sesuai dengan posisi yang berbicara dan yang diajak berbicara. Ada tiga unggah-ungguh basa Madya ialah a) Madya Ngoko, b) Madya Krama, dan c) Madyantara.

3. Basa Krama, dibagi menjadi enam macam, “... Krama lugu, Mudha Krama, Wrédha Kedhaton.” Nugraha \& Tofani, (2006:11) Krama, Krama Inggil, Krama Désa dan Basa.

4. Basa Semu utawa samudana

Semu, diartikannya sebagai sesuatu yang menyerupai, atau seolah-olah. Endraswara 
(2003: 24) mengungkapkan mengenai bahasa semu.

\begin{abstract}
"Basa Semu, merupakan ungkapan dari orang Jawa untuk menampilan segala sesuatu, dalam bentuk isyarat atau sasmita, terselubung, dengan menggunakan tandatanda khas"
\end{abstract}

Basa Semu, adalah bahasa tersamar untuk mengekspresikan pikiran, perasaan, dan kemauan secara terselubung (tampaknya, seperti) dari seseorang kepada orang lain. Di lingkungan masyarakat Jawa, ajaran atau bimbingan yang ditanamkan orang tua kepada anak, menjadi halus ketika menggunakan Basa Semu ini. Orangtua menanamkan nilai moral, budaya dan agama, secara tersamar atau tidak langsung. Seperti yang di ungkapkan Endraswara, (2003: 25)

"Masyarakat Jawa tradisional, mengaktualisasikan sikap dan tingkahlakunya ke dalam wujud yang tidak jelas (disamarkan). Ajaran-ajaran moral yang menyangkut sikap hidup khas orang Jawa, selalu dirahasiakan (tidak terang-terangan)".

Penggunaan Basa Semu dalam hubungan sosial antara orang satu dengan yang lain, baik dalam keluarga, sekolah dan masyarakat, digambarkan sebagai berikut. (1) Basa Sеmu, cara yang digunakan orang tua untuk mendidik anak, terutama ajaran-ajaran moral dilaksanakan secara tidak langsung (tidak terus terang), dengan menggunakan tembung-tembung, ukara-ukara semu atau samudana. (2) Basa Semu merupakan cara yang digunakan untuk menyampaikan gagasan atau pendapat terutama hal-hal yang dianggap rahasia kepada orang lain agar tetap terjaga dan tercipta suasana hubungan yang mengenakkan. (3) Basa Semu dipakai sebagai pernyataan sikap, tingkahlaku tersamar. Basa Semu merupakan bentuk kehalusan budi orang Jawa dalam membina hubungan individu satu dengan yang lain. (4) Basa Semu dijadikan acuhan tingkat penguasaan Basa Jawa, sebagai cermin budaya. Semakin hebat penguasaan bahasa dan budaya seseorang, maka semu atau simbol yang digunakan semakin rumit. Menariknya, apabila seseorang semakin rumit dan halus Basa Semu atau simbol yang digunakan, maka akan mendongkrak status sosial orang tersebut. (5) Orang Jawa yang telah mampu menggunakan Basa Semu dan mampu membaca semu, tergolong jalma limpat seprapat tamat. Maksud kalimat tersebut adalah untuk menggambarkan orang yang mampu menangkap dan memahami isi pesan yang disampaikan orang lain, meskipun hanya berupa isyarat halus.

Orang yang telah digolongkan sebagai jalma limpat seprapat tamat tersebut, adalah orang yang telah mampu menggunakan daya nalar (reasoning) dan rasa sekaligus. Sri Mangkunegara IV dalam serat Wedhatama, Harsono, (2005: 58) menyebut: "Wong kang wus waspada ing patrap, mangayut ayat winasis, nèng rasa tumlawung." Artinya, orang yang telah mampu membaca isyarat, tahu pesan terselubung, dan faham atas rasa. Contoh Basa Sетu yang dipakai dalam komunikasi di lingkungan masyarakat Jawa untuk percakapan sehari-hari.

1) Yu, sampéyan nembé bibar gerah yo, olèhé dhahar ngembang jambu. Kembang jambu namanya karuk=kemaruk (ketika makan sangat banyak). Maksudnya, orang menyampaikan sindiran karena makan demikian banyaknya.

2) Dik, anggonmu ngendika iku disuda aja ngembang jéngkol waé. Kembang jéngkol namanya kecuwis=omong ngeciwis (berbicara terus).

3) $\mathrm{Bu}$, ana masalah apa ta pasuryan panjenengan ngembang kacang terus? Kembang kacang namanya besengut $=$ pasuryané mbesengut (muka cemberut)

\section{Metode Penelitian}

\section{Sampling dan Satuan Kajian}

Teknik sampling dalam penelitian kualitatif berbeda dengan penelitian non-kualitatif. Pada penelitian kualitatif, erat kaitannya dengan faktorfaktor kontekstual. Maksud sampling adalah menjaring atau menggali sebanyak mungkin informasi dari berbagai macam sumber dan bangunannya (constructions). Penelitian kualitatif tidak ada sampel acak, tetapi sampel bertujuan atau purposive sample dan teknik inilah yang digunakan dalam penelitian. Ada empat ciri-ciri sampel penelitian kualitatif menurut Moleong, (1999: 224225). 
"Sampel bertujuan dapat diketahui dari ciricirinya: 1). Rancangan sampel yang muncul, ... 2). Pemilihan sampel secara berurutan, ... 3). Penyesuaian berkelanjutan dari sampel, ... 4). Pemilihan berakhir jika sudah terjadi pengulangan".

Ciri pertama, rancangan sampel penelitian kualitatif, tidak dapat ditentukan dan ditarik terlebih dahulu, tetapi muncul di lapangan. Peneliti ketika mengambil data dari subyek, belum mempunyai kepastian jumlah sampel. Ciri ke dua, pemilihan sampel secara berurutan. Artinya, untuk mendapatkan informasi yang cukup banyak dan mendalam, dapat dilakukan apabila sampel sebelumnya sudah dijaring dan dianalisis. Setiap satuan sampel berikut, dapat dipilih untuk memperluas informasi yang telah diperoleh dari sampel sebelumnya. Demikian seterusnya sehingga informasi yang baru diperoleh, dapat dipertentangkan atau dilengkapi dengan informasi yang ditemukan pada sampel berikutnya.

Ciri ke tiga, penyesuaian berkelanjutan dari sampel, artinya pada permulaannya setiap sampel memberikan informasi yang sama. Kemudian makin banyak informasi yang diterima dan makin berkembang data yang diperoleh sesuai dengan obyek penelitian. Apabila masih dipandang perlu, maka dilakukan pengambilan sampel berikut (berkelanjutan) untuk memperoleh informasi yang lebih banyak dan lebih baru tentang obyek penelitian. Ciri ke empat, pemilihan berakhir ketika sudah terjadi pengulangan. Maknanya, jumlah sampel ditentukan oleh pertimbanganpertimbangan informasi yang diperlukan. Jika sudah tidak ada lagi informasi yang dapat dijaring, maka pengambilan sampel dihentikan.

\section{Satuan kajian}

Penentuan sampel, strategi sampling, pada dasarnya tergantung pada penetapan satuan kajian. Satuan kajian bersifat perorangan misalnya, anak, orangtua, klien. Apabila satuan kajian adalah perorangan, maka pengumpulan data dipusatkan di sekitarnya. Data atau informasi yang dikumpulkan ialah apa yang terjadi dalam kegiatannya, apa yang mempengaruhinya, bagaimana tingkahlakunya. Sebaliknya apabila satuan kajian adalah kelompok, maka satuan kajiannya adalak kelompok, misalnya aktivitas penduduk, norma-norma sosial, adatistiadat masyarakat.
Pada penelitian, penulis menggunakan satuan kajian perorangan dengan subyek penelitian adalah sejumlah orangtua di desa Gilangharjo Pandak Bantul.

\section{Teknik Pengumpulan Data}

\section{Teknik wawancara tak terstruktur.}

Teknik wawancara tidak terstruktur, disebut pula teknik wawancara mendalam, wawancara intensif, wawancara kualitatif, atau wawancara terbuka, mirip dengan percakapan informal. Teknik ini bersifat fleksibel, susunan kata dan pertanyaannya, disesuaikan dengan ciri-ciri setiap responden. Wawancara tak terstruktur, juga penting untuk memperoleh informasi untuk menemukan hal-hal yang dipikirkan dan dirasakan subyek mengenai peristiwa-peristiwa tertentu.

Kriteria dan teknik pemeriksaan keabsahan data

1. Kriteria keabsahan data

Penetapan keabsahan data yang dikumpulkan, diperlukan teknik pemeriksaan. Pelaksanaan teknik pemeriksaan, digunakan kriteria derajat kepercayaan (credibility). Kriteria ini pada dasarnya menggantikan konsep validitas internal pada penelitian kuantitatif. Ada tujuh teknik pemeriksaan keabsahan data dengan kriteria kredibilitas (derajat kepercayaan), dan salah satunya adalah teknik triangulasi. Teknik triangulasi sebagai cara untuk pemeriksaan keabsahan data. Triangulasi adalah tehnik pemeriksaan keabsahan data yang memanfaatkan data lain. Data lain dimaksud, digunakan sebagai pembanding data yang telah berhasil dikumpulkan. Triangulasi mempunyai empat macam teknik pemeriksaan dengan menggunakan sumber, metode, peneliti dan teori. Di antara keempat macam teknik triangulasi tersebut, peneliti menggunakan teknik pemeriksaan memanfaatkan penggunaan sumber data. Sumber data yang dimaksud adalah anak dan isteri. Data yang dikumpulkan dari subyek, kemudian dibandingkan dengan data yang dikumpulkan dari anak dan isteri. Keabsahan data subyek terjadi apabila ada dukungan dari data yang disampaikan anak dan isteri.

2. Kriteria analisis dan interpretasi data

a. Aktifitas kepemimpinan

Aktivitas kepemimpinan mengandung empat komponen: 1) menggerakkan, 2) mengarahkan, 3) memotivasi, dan 4) 
menyelaraskan. Keempat komponen kepemimpinan tersebut dijadikan kriteria untuk meng analisis dan interpretasi aktifitas kepemimpinan orangtua dalam mendidik anak.

b. Kualitas kepemimpinan pendidikan

Kriteria untuk menganalisis dan menginterpretasi kualitas kepemimpinan dalam mencapai tujuan, didasarkan pada tiga macam kepemimpinan, ialah kepemimpinan direktif, suportif dan partisipatif. Ketiga kepemimpinan tersebut, masing-masing mempunyai ciri-ciri yang menunjukkan kualitas dari seorang pemimpin dan ciri-ciri kualitas ini yang menjadi kriteria analisis dan interpretasi data.

c. Kriteria keberhasilan kepemimpinan pendidikan

Kriteria untuk menentukan keberhasilan tingkahlaku manusia secara obyektif sulit, karena harus melibatkan sejumlah aspek yang terkait pada tingkahlaku itu, yaitu meningkatnya efektivitas kepemimpinan dan tujuan atau target yang diinginkan tercapai.

d. Kriteria tipe kepemimpinan pendidikan

Kriteria yang digunakan sebagai pembanding pada tipe-tipe kepemimpinan subyek mendidik anak belajar dan berbicara unggah-ungguh basa dan Basa Semu, meliputi kepemimpinan otokratik, demokratik dan permisif dengan ciri masing-masing.

Ciri-ciri kepemimpinan otokratik 1) komunikasi dilakukan secara tertutup dan satu arah, 2) memiliki kepercayaan diri yang rendah terhadap anak, 3) menentukan kebijaksanaan sendiri, apabila musyawarah sifatnya hanya penawaran saja, 4) anak oleh pimpinan dianggap sebagai pelaksana, mereka tidak boleh memberikan ide-ide baru, 5) beban belajar, ditanggung oleh pimpinan, 6) korektif dan minta penyelesaian tugas belajar pada waktu sekarang.

Ciri-ciri tingkahlaku kepemimpinan demokratis: 1) beban belajar menjadi tanggung jawab bersama, 2) anak dianggap sebagai komponen pelaksana, dan secara integral harus diberi tugas \& tanggung jawab, 3) disiplin, tidak kaku, dalam memecahkan masalah belajar dilakukan bersama, 4) kepercayaan terhadap anak tinggi dengan tidak melepas tanggung jawab pengawasannya, 5) komunikasi dengan anak bersifat terbuka, dua arah.

Ciri-ciri tingkahlaku kepemimpinan permisif: 1) Tidak ada pegangan yang kuat dan kepercayaan diri yang rendah, 2) mengiyakan semua saran, lambat membuat keputusan, 3) mengambil muka kepada anak, 4) ramah dan tidak menyakiti anak.

\section{Hasil dan Pembahasan}

Berdasarkan data dari 6 subyek penelitian, kemudian dianalisis dan diinterpretasikan, hasilnya menunjukkan sebagai berikut.

1. Orangtua jarang menggerakkan, mengarahkan, memotivasi dan mengontrol anak belajar berbicara unggah-ungguh basa Basa Semu.

2. Orangtua tidak mempunyai tujuan \& target yang harus dicapai anak dalam belajar dan berbicara unggah-ungguh basa dan Basa Semu.

3. Orangtua tidak mengatur, menyediakan waktu harian/mingguan untuk mengajarkan, membimbing, melatih dan tidak memberi waktu untuk bertanya jawab atau berdiskusi bersama anak tentang pembelajaran dan berbicara unggahungguh basa dan Basa Semu.

4. Orangtua menggunakan Basa Ngoko setiap hari di keluarga sehingga anak kurang perhatian belajar dan berbicara bahasa tersebut.

5. Orangtua sadar bahwa unggah-ungguh basa dan Basa Semu baik untuk anak, tetapi belum mampu mengatur waktu untuk memimpin dan mendidik anak belajar dan berbicara secara kontinu.

6. Orangtua tidak menggunakan salah satu atau ketiga-tiganya dari pola kepemimpinan direktif, suportif, partisipatif dalam mendidik anak belajar dan berbicara unggah-ungguh basa dan Basa Sетu. Kepemimpinan orangtua berlangsung secara insidental, tanpa pola.

7. Orangtua jarang memberi arahan, tugas, motivasi, kontrol, dalam mengajar, membimbing, dan melatih anak belajar dan berbicara unggahungguh basa dan Basa Semu baik fonologi, semantik, sintaksis maupun pragmatis.

8. Orangtua tidak pernah bekerja sama dengan anak untuk mengoreksi kekurangan dan kelemahan dalam belajar dan berbicara unggah-ungguh basa dan Basa Semu.

9. Orangtua kurang mengerti tercapai atau tidaknya tujuan dan target kepemimpinan mendidik anak 
KEPEMIMPINAN ORANG TUA, PENDIDIKAN ANAK, UNGGAH-UNGGUH BASA

belajar dan berbicara unggah-ungguh basa dan Basa Semu, karena tidak ada tujuan dan target yang harus dicapai anak.

10. Orangtua tidak efisien dan efektif dalam kepemimpinan mendidik anak belajar dan berbicara bahasa tersebut karena tidak pernah mengontrol dan mengevaluasi kemajuan anak.

11. Kepemimpinan orangtua mendidik anak belajar dan berbicara unggah-ungguh basa dan Basa Semu, lebih banyak dengan membiarkan anak belajar sendiri dan belajar dari orang lain.

12. Kepemimpinan mendidik anak belajar dan berbicara sesuai unggah-ungguh basa dan Basa Semu, lebih banyak menunjukkan ciri-ciri dari tipe kepemimpinan permisif, ditandai antara lain:

a. Mengiyakan apabila ada saran dari orang lain tetapi tak pernah dilakukan,

b. Lambat membuat keputusan, berbaik hati kepada anak, ramah, tidak menyakiti hati anak.

c. Tidak ada pegangan kuat dan kepercayaan diri rendah

d. Ramah dan tidak menyakiti anak

13. Orangtua menguasai dan dapat menggunakan Krama Lugu, Krama Inggil, Basa Semu, Sanépan dan Pepindhan, tetapi tidak mampu mewariskan nilai-nilai tersebut melalui kepemimpinan mendidik anak.

14. Hambatan-hambatan yang dihadapi kepemimpinan orangtua mendidik anak belajar dan berbicara unggah-ungguh basa dan Basa Semu anak.

a. Ketidakmampuan orangtua mengelola waktu yang tersedia untuk memberikan layanan anak belajar dan berbicara unggah-ungguh basa dan Basa Semu.

b. Orangtua tidak memiliki tujuan dan target yang jelas dalam kepemimpinan mendidik anak belajar dan berbicara unggah-ungguh basa dan Basa Semu.

c. Orangtua membiasakan Basa Ngoko sebagai bahasa komunikasi keluarga sehari-hari. Krama Lugu dan Krama Inggil, jarang digunakan dan Basa Semu, Sanépan dan Pepindhan sama sekali tidak pernah digunakan.

d. Anak kurang berminat menggunakan Krama Lugu dan Krama Inggil serta Basa Semu sebagai bahasa komunikasi, karena setiap hari menggunakan Basa Ngoko dan Bahasa Indonesia sebagai bahasa pergaulan.
15. Hal-hal yang diketemukan dalam penelitian

a. Orangtua mengerti, menguasai dan dapat mengaplikasikan unggah-ungguh basa, baik Krama Lugu maupun Krama Inggil dan Basa Semu, tetapi tidak mampu menunjukkan kepemimpinannya sebagai pendidik dalam mengajar, membimbing dan melatih bahasa tersebut kepada anak.

b. Orangtua sadar bahwa unggah-ungguh basa dan Basa Semu mempunyai nilai budaya yang luhur dan menjadi ciri khas budaya Jawa tetapi secara aktif tidak mampu mewariskan nilai-nilai tersebut melalui kepemimpinan pendidikan

c. Basa Semu tidak digunakan dan kurang diperhatikan oleh orangtua dan anaknya sebagai bahasa komunikasi baik di keluarga maupun di masyarakat. Basa Sетu hanya digunakan ketika upacaraupacara adat berlangsung baik di keluarga maupun di masyarakat.

\section{Simpulan}

Hasil penelitian disimpulkan sebagai berikut.

1. Kepemimpinan orangtua mendidik anak belajar dan berbicara unggah-ungguh basa dan Basa Sетu di lingkungan desa Gilangharjo, Pandak, Bantul, kurang aktif, kurang berkualitas dan tidak berhasil.

2. Orangtua mengerti dan terampil berbicara unggah-ungguh basa baik Krama Lugu maupun Krama Inggil, tetapi kepemimpinan mendidik anak belajar dan berbicara bahasa tersebut, tidak aktif dilakukan

3. Orangtua mengerti dan terampil berbicara unggah-ungguh basa baik Krama Lugu maupun Krama Inggil, tetapi kepemimpinan mendidik anak belajar dan berbicara bahasa tersebut, kurang berkualitas.

4. Orangtua mengerti dan terampil berbicara unggah-ungguh basa baik Krama Lugu maupun Krama Inggil, tetapi kepemimpinan mendidik anak belajar dan berbicara bahasa tersebut, tidak berhasil.

5. Orangtua mengerti, dapat berbicara Basa Semu, tetapi kepemimpinan mendidik anak dalam belajar dan berbicara bahasa tersebut, tidak aktif melakukan, kurang berkualitas dan tidak berhasil. 
6. Tipe kepemimpinan orangtua mendidik anak belajar dan berbicara unggah-ungguh basa dan Basa Sетu di lingkungan masyarakat desa Gilangharjo, Pandak, Bantul adalah tipe permisif.

\section{Arti Penting Hasil Penelitian}

Berdasarkan beberapa pertimbangan antara lain: 1) Hasil analisis dan interpretasi data, 2) Kesimpulan penelitian, 3) Hal-hal yang diketemukan dalam penelitian, 4) Hambatan-hambatan yang dihadapi, dan 5) Manfaat hasil penelitian bagi orangtua, guru, pemerhati budaya, para peneliti terutama yang berminat pada penelitian budaya, aparat pemerintah, pimpinan lembaga pendidikan, dan lain-lain, maka makna penting dari hasil penelitian adalah sebagai berikut.

1. Bagi pengembangan akademik

a. Nilai-nilai budaya termasuk budaya lokal, harus dimasukkan dalam kurikulum. Bagi lembaga pendidikan (pendidikan dasar, menengah dan tinggi) yang sudah memasukkan muatan budaya, ditinjau ulang untuk ditambahkan jam-jam pembelajarannya.

b. Memberikan pelatihan terkait dengan penguasaan, ketrampilan menanamkan nilai budaya kepada para pelaksana pendidikan utamanya guru, mengingat yang menjadi sasaran pendidikan bukan hanya kognitif tetapi juga afektif dan psikomotoprik. Penanaman nilai kognitif, menggunakan sejumlah metode mengajar, sedangkan penanaman nilai afektif, lebih utama menggunakan filsafat (falsafah). Falsafah ada dan bersumber pada budaya dan agama. Dengan demikian merupakan keharusan bagi pengembang, pelaksana pendidikan, untuk memahami dan menguasai falsafat sebagai alat penanaman nilai moral kepada anak.

2. Bagi pembina dan pengembang moral kepribadian bangsa.

Sasaran pendidikan bukan hanya mengembangkan kemampuan kognitif anak, tetapi juga karakter mereka. Isi pendidikan karakter adalah nilai-nilai moral yang mancakup nilai baik dan buruk, benar dan salah. Pembentukan karakter dengan cara menanamkan nilai-nilai moral yang ada dan bersumber pada budaya dan agama, akan membentuk karakter anak yang kuat dan baik.
Anak-anak yang memiliki karakter dengan nilainilai moral yang baik, akan menjadi kader dan calon pemimpin bangsa yang baik pula.

3. Generasi muda saat kini perkembangan kognitifnya sangat baik. Generasi muda adalah generasi muda Indonesia yang sangat baik perkembangan pola berfikirnya, tetapi kurang diimbangi dengan perkembangan moral mereka. Generasi muda telah mengalami degradasi moral yang ada pada nilai budaya dan agama. Tingkah laku mereka tidak sesuai dengan etika dan tatakrama, moral budaya dan agama, bahkan sudah tidak mengenal budaya daerahnya. Keadaan itu menunjukkan bahwa peran orangtua dan guru yang berkewajiban menanamkan nilai moral, budaya dan agama kurang berhasil.

4. Saran-saran untuk penelitian lanjutan

a. Penelitian yang penulis lakukan, masih terbatas pada kepemimpinan orangtua mendidik anak, sehingga masih dapat dilanjutkan pada penelitian berikut ditinjau dari kepemimpinan baik kepemimpinan Kepala Sekolah, para guru, para tokoh agama dan masyarakat.

b. Penelitian yang penulis lakukan, masih terbatas di lingkungan masyarakat desa Gilangharjo Pandak Bantul, oleh karena itu penelitian lanjut dapat dilakukan di lingkungan lain sehingga dapat melengkapi penelitian yang penulis lakukan.

\section{Referensi}

Abdul Halim. (2000). Menghias Diri dengan Akhlaq Terpuji, Yogyakarta: Mitra Pustaka.

Abdur Rahman. (2005). Tahapan Mendidik Anak. Bandung: Irsyad Baitus Salam.

Ali, Muhammad. (2002). Guru dalam Proses Belajar Mengajar. Bandung: Sinar Baru Algensindo.

Assegaf, Abdul Rahman. (2004). Pendidikan Tanpa Kekerasan. Yogyakarta: Tiara Wacana Yogya.

Anderson, Benedict R.G. (2003). Metologi dan Toleransi Orang Jawa, (Penerjemah: Revianto B. Santoso dan Lutfi Wulandari), Yogyakarta: Penerbit JEJAK.

Ahmadi, Abu. (2007). Psikologi Sosial. Jakarta: Penerbit Rineka Cipta. 
Bambang \& Hanny Syumanjaya. (2010). Just for Parents: Bacaan Wajib Orangtua dan Pendidik. Jakarta: PT. Gramedia Pustaka Utama.

Baron, Robert A, \& Donn Byrne. (2005). Psikologi Sosial. (alih bahasa Ratna Djuwita). Jakarta: Penerbit Erlangga.

Chang, William. (2007). Merawat Reputasi Bangsa, (Kompas). Jakarta: 14 Agustus, hlm. 16.

Chazan, Berey. (1992). Contemporary Approaches to Moral Education, New Jersey: Englewood Cliff.

Clark, H.H. \& Clark, E.V. (1977). Psychology and Language: Introduction to Psycholinguistics, New York: Harcourt Brace Jovanovich, Publiser.

Dagun, Save M. (1990). Psikologi Keluarga, Jakarta: Penertbit Rineka Cipta.

Danim, Sudarwan. (2004). Motivasi Kepemimpinan dan Effektivitas Kelompok. Jakarta: Penerbit Rineka Cipta.

Dardjowidjoyo, S. (2003). Psikolinguistik: Pengantar Pemahaman Bahasa Manusia, Jakarta: Yayasan Obor Indonesia.

Dayakisni Tri, dan Sulis Yumardi. (2004). Psikologi Lintas Budaya. Malang: UMS Press.

Departemen Pendidikan Nasional. (2002). Kamus Besar Bahasa Indonesia. Jakarta: Balai Pustaka.

Eggen, Paul, and Don Kauchak. (1994). Educational Psychology. New Jersey: Englewood Cliffs.

Endraswara, Suwardi. (2003). Falsafah Hidup Jawa. Tangerang: Penerbit Cakrawala.

Enoh, Muchamad, (2006). Pengaruh Perilaku Kepemimpinan Dosen Dalam Proses Belajar Mengajar, Kualitas Layanan Akademik, Kualitas Layanan Administratif, Terhadap Tingkat Kepuasan Mahasiswa Universitas Negeri Surabaya. Thesis tidak diterbitkan. Yogyakarta: Program Pasca Sarjana UNY.

Fadlun, Muhammad. (2009). Kumpulan Khutbah Jum'at Bahasa Jawi Akhir Zaman. Surabaya: Pustaka Agung Harapan.

Fatimah, Siti. (2005). Pengaruh Gaya Kepemimpinan Kepala Sekolah terhadap Etos Kerja Guru Menurut Persepsi Guru di SLTP Negeri Kabupaten Gunung Kidul, Yogyakarta, Tesis tidak diterbitkan. Yogyakarta: Program Pasca Sarjana UNY.

Feldman, Robert S. (1999). Understanding Psychology. New York: McGraw-Hill College.
Fieldmon, C. D, \& Arnold, H. J. (1990) Managing Individual and Group Behavioral in Organization. Auckland: McGraw Hill Book Company.

Fielder, Fred E, Martin \& M. Ehemers. (1984). Leadership and Effective Management. Illionis: Scott, Forewsmen, and Company.

Ghazali, Imam. (2005). Rahasia Ketajaman Mata Hati, (Alih Bahasa, Fatihuddin Abul Yasin). Surabaya: Penerbit Terbit Terang.

Gerric, Richard J. \& Philip G., Zimbardo. (2005). Psychology. New York: Person.

Gordon, R.A., RW, \& Sharplin, A., et. al. (1990) Management and Organizational Behavior, Boston: Allyn and Bacon.

Greenberg, J, \& Baron, R.A. (1995). Behavior and Organization: Understanding and managing the human side of work, Englewood Cliffs: Prentice Hall, Inc.

Halim, M. Nipan Abdul. (2000) Menghias Diri dengan Akhlaq Terpuji, Yogyakarta: Mitra Pustaka.

Hamengku Buwono X, Sri Sultan. (15 Nopember 2006) Aspek pendidikan, moral dan ajaran hidup dalam naskah keraton Yogyakarta. Keynote Speech Seminar Khasanah Budaya Keraton Yogyakarta. (Makalah).

(18 Oktober 2011). Tantingan. Yogyakarta: (Kedaulatan Rakyat). (19 Oktober, 2011). Pernikahan Putri Kanjeng Ratu Bendara. Yogyakarta: (Kedaulatan Rakyat).

Harsono, Andi. (2005). Tafsir Ajaran Serat Wulangreh. Yogyakarta: Pura Pustaka.

Hasan, Aliah B. Purwakania. (2006). Psikologi Perkembangan Islami. Jakarta: PT Raja Grafindo Persada.

Hastuti, Sri. (1999). Faktor-faktor Penunjang Bahasa Indonesia Sekolah Dasar Kelas Permulaan di Daerah Istimewa Yogyakarta. Disertasi tidak diterbitkan. Yogyakarta: IKIP Yogyakarta.

Hersey, Paul, and Kennenth H. Balnchard. (1998). Management Organization Behavior. New Jersey: Prantice Hall, Inc., Englewood Cliffs.

Herusatoto, H. Budiono, (2008). Banyumas Sejarah, Budaya, Bahasa, dan Watak. Yogyakarta: PT LKiS Pelangi Aksara Yogyakarta. 
Hurlock, Elizabet. (2002). Psikologi Perkembangan, Bandung: Penerbit Bulan Bintang.

Ihsan, Fuad. (2003). Dasar-dasar Kependidikan, Yogyakarta: Rineka Cipta.

Ilyas Yunahar. (2004). Kuliah Akhlak, Yogyakarta: Pustaka Pelajar Offset.

Jabir. Abu Bakr Al-Jazairi. (2005). Ensiklopedi Muslim, Jakarta: PT. Darul Falah,.

Jay Robert,R. (1979). Religion and Politics in Rural Central Java, New Haven: Yale University.

Kahono. (1992). Lagu Sekar Macapat. Yogyakarta.

Kartini, Kartono. (1983). Pemimpin dan Kepemimpinan, Jakarta: PT Raja Grafindo Persada.

Kawuryan, Megandaru W. (2008). Kamus Lengkap Jawa-Indonesia, Indonesia-Jawa. Yogyakarta: Panji Pustaka.

Kementerian Agama Republik Indonesia. (1960) Rerepèn Tladjer-Ugering Balé Grijo. Jogjakarta: Kantor Penerangan Agama DIJ.

Kincaid Lawrence,\& Wilbur Schramm. (1997) Azas-azas Komunikasi Antar Manusia, Terj. Jakarta: LP3ES.

King, Laura A. (2008). Psychology. New York: McGraw-Hill College.

Koentjaraningrat. (1977). Metode-metode Penelitian Masyarakat. Jakarta: PT. Gramedia Pusaka Utama.

Kridalaksana Harimurti, Rahyono Dwi Puspitasari, Supriyanto Wododo dan Darmoko. (2001) Wiwara Pengantar Bahasa dan Kebudayaan Jawa. Jakarta: PT Gramedia Pustaka Utama.

Kuntowijoyo, (2006). Budaya dan Masyarakat, Yogyakarta: Tiara Wacana Yogya.

Kurniati, Listya Sulastri Wulan. (2009). Degradasi Moral Kepemimpinan Dalam Novel Hubbu Karya Mashuri: Kajian Strukturalisme Genetik. Thesis tidak diterbitkan. Yogyakarta: Fakultas Ilmu Budaya UGM.

Liliweri, Alo. (2011). Dasar-dasar Komunikasi Antar Budaya, Yogyakarta: Pustaka Pelajar.

Lipham, James M. (1985). The Principalship Concepts, Competencies and Cases. London: Longman, Inc.

Lubis, Mawardi. (2008). Evaluasi Pendidikan Nilai. Yogyakarta: Pustaka Pelajar.

Lunenberg, F. C., \& Ornstein, A.C. (2000). Educational Administration: Concept and
Practices, Belmont: Wardsworth, A Division of Thomson Learning.

Mahfud, Choirul. (2011). Pendidikan Multikultural, Yogyakarta: Pustaka Pelajar.

Mardjoned, H. Ramlan. (2003). Keluarga Sakinah Rumahku Syurgaku, Jakarta: Media Da'wah.

Marwoto, Sindung. (2008). Ramalan Prabu Jayabaya Mengungkap Tanda-tanda Zaman, Yogyakarta: Panji Pustaka.

Matsumoto. (2008). Cultures and Psychology, San Fransisco: Books Cole Publishing Company.

Mendiknas, Undang-Undang Republik No. 20, Tentang Sistem Pendidikan Nasional 2003.

Moelono, Anton Moedardo. (1981). Pengembangan dan Pembinaan Bahasa: Ancangan Alternatif Di Dalam Perencanaan Bahasa. Disertasi tidak diterbitkan. Jakarta: Universitas Indonesia.

Moleong, Lexy J. (1999). Metodologi Penelitian Kualitatif. Bandung: PT. Remaja Rosdakarya. . (2010). Metodologi Penelitian Kualitatif, Bandung: PT. Remaja Rosdakarya.

Muhadjir, Noeng, (2001). Identifikasi Faktor-faktor Opinion Leader Inovatif bagi Pembangunan Masyarakat, Yogyakarta: Penerbit Rake Sarasin.

Muhaimin. (2004). Paradigma Pendidikan Islam, Bandung: PT. Remaja Rosdakarya.

Mujahid, Abdul Malik. (2002). Al-Qur'an dan Terjemahannya. Jeddah: Darussalam Global Leadewr in Islamic Books.

Mulyana, Deddy, dan Jalaluddin Rakhmat. (2003). Komunikasi Antar Budaya, Bandung : Penerbit PT. Remaja Rosda Karya.

Mulyana, Deddy. (2003). Metodologi Penelitian Kualitatif, Bandung: PT Remaja Rosdakarya.

Mulyana, Rohmat. (2004). Mengartikulasikan Pendidikan Nilai, Bandung: Penerbit Alfabeta.

Muslich, KS., (2006). Moral Islam dalam Serat Piwulang Paku Buwono IV, Yogyakarta: Global Pustaka Utama.

Nugraha, Setyo dan M. Abi Tofani, (2006). Buku Pinter Basa Jawa, Yogyakarta: Penerbit Kartika.

Patton, Michael Quinn. (2006). Metode Evaluasi Kualitatif, Penerjemah: Budi Puspo Priyadi. Yogyakarta: Pustaka Pelajar.

Partini, (2010). Sinau Unggah-ungguhing Basa Jawi, Yogyakarta: Panji Pustaka.

Popham, W. James. and Evaq L. Baker. (2001) Teknik Mengajar Secara Sistematis, 
diterjemahkan Amirul Hadi. Jakarta: Rineka Cipta.

Prabowo, DP., Tatakramanipun Dhahar. (21 Nopember 2012.) Yogyakarta: Kedaulatan Rakyat.

Purwadi. (2005). Unggah-ungguh basa Jawi. Yogyakarta: Hasna Pustaka.

Purwanto, Metodologi Penelitian Kualitatif, Yogyakarta: Pustaka Pelajar, 2008.

Purwanto, Eko. (2011). Pepak Bahasa Jawi, Yogyakarta: DIVA Press.

Purwanto, M, Ngalim. (2007). Ilmu Pendidikan, Teoris dan Praktis. Bandung: PT. Remaja Rosdakarya.

(2010). Psikologi Pendidikan, Bandung: PT. Remaja Rosdakarya.

Raharjo, S.G. (2008). Kawruh Basa Jawa Pepak, Semarang : Widya Karya.

Rahman, Jamaal Abdur. (2000). Tahapan Mendidik Anak, Bandung: Irsyad Baitus Salam.

Rakhmat, Jalaluddin. (2008). Psikologi Komunikasi, Bandung: PT. Remaja Rosdakarya.

Rokhman, Fathur. (2003). Pemilihan Bahasa Dalam Masyarakat Dwibahasa: Kajian Sosiolinguistik di Banyumas. Disertasi tidak diterbitkan. Yogyakarta: Fakultas Ilmu Budaya UGM.

Roqib, Moh. (2007). Harmoni Dalam Budaya Jawa, Yogyakarta: Pustaka Pelajar.

Rustama, Kuswara Tisna. (2004). Inovasi dalam Pertunjukan Wayang Golek Sunda, Disertasi tidak diterbitkan. Yogyakarta: Universitas Gadjah Mada.

Rustopo. (2006). Menjadi Jawa: Orang-orang Cina dan Kebudayaan Jawa di Surakarta. Disertasi tidak diterbitkan. Yogyakarta: Fakultas Ilmu Budaya UGM.

Russell, Veitch \& Daniel Arklelin. (1999). Environmental Psychology, New Jersey: Englewood Cliff.

Saifudin, Muhammad. (2011). Al-Qur'anulkarim Miracle the Refference, Bandung: PT Sygma Examedia Arkanleema.

Santoso, Yudi. (2010). Kamus Psikologi, Yogyakarta: Pustaka Pelajar.

Satori, M., Penelitian Kualitatif, Bandung: PT. Remaja Rusda Karya, 2009.

Santrock, John W., and Jane S. Halonen. (1999) Psychology, New York: McGraw-Hill College.

Sardiman. Etika dan sopan santun. Yogyakarta: Kedaulatan Rakyat 20 Januari 2010.
Setiyanto, Aryo Bima. (2007). Parama Sastra Bahasa Jawa, Yogyakarta: Panji Pustaka.

Shadily, Hassan. (1980). Ensiklopedi Umum, Yogyakarta: Percetakan offset Kanisius.

Siagian, S.P. (1995). Peranan Staff dalam Managemen, Jakarta: PT Gunung Agung.

Sobary, Muhammad, Peduli Budaya Local dan Pariwisata Nusantara, (Makalah), Semarang: Disampaikan dalam seminar mahasiswa Fakultas Sastra Universitas Diponegoro, 22 Juni 2000.

Stockdale, J.Y. (2010). Eksotisme Jawa: Ragam Kehidupan dan Kebudayaan Masyarakat Jawa, Yogyakarta: Penerbit Progresif Book.

Sudarmanto. (2008). Kamus Lengkap Bahasa Jawa: Jawa-Indonesia, Indonesia-Jawa, Semarang: CV. Widya Karya.

Sugiyono. (2010). Penelitian Pendidikan, Bandung: Penerbit Alfabeta.

(2011). Statistika untuk Penelitian, Bandung: Penerbit Alfabeta.

Sukmadinata, Nana Saudih. (2003). Landasan Psikologi Proses Pendidikan, Bandung: PT. Remaja Rosdakarya.

Sumarlan, Pembelajaran Bahasa Jawa Dinilai Gagal, dalam Kedaulatan Rakyat, Yogyakarta: 6 April 2011.

Sumarno, TH. (2005). Pengaruh Kepemimpinan dan Kompetensi Terhadap Kinerja Lulusan Diklat Pimpinan Angkatan IV Pegawai Negeri Sipil Di Lingkungan Balai Diklat Departemen Pekerjaan Umum Wilayah III Yogyakarta Tahun 2003 dan 2004. Tesis tidak diterbitkan. Yogyakarta: Program Pasca Sarjana UNY.

Sumidjo, Wahjo. (1999). Kepemimpinan Kepala Sekolah. Jakarta: Raja Grafindo Persada.

Sumukti, Tuti. (2006) Semar Dunia Batin Orang Jawa, Yogyakarta: Penerbit Galang press.

Suseno, Franz Magnis. (2003). Etika Jawa, Jakarta : PT. Gramedia Pustaka Utama.

Susetya, Wawan. (2007). Ular-ular Manten Wejangan Perkawinan Adat Jawa, Yogyakarta: Penerbit Narasi.

Suwaji, Dirgo Sabariyanto, Slamet Riyadi, dan Samid Sudiro. (1986). Morfosintaksis Bahasa Jawa. Jakarta: Pusat Pembinaan dan Pengembangan Bahasa Depdikbud,. (1991). Perbandingan Sistem Morfologi Verba Bahasa Jawa dengan Sistem Morfologi Verba Bahasa Indonesia. Jakarta: Depdikbud. 


\section{EFFENDI}

Tafsir, A.. (2003). Pendidikan Kejuruan, Jakarta: Rineka Cipta.

Taufiq, Nurdjanah dan Rukmini Barhana. (1999). Pengantar Psikologi, Jakarta: Penerbi Erlangga.

Terry, George, R. (1987). Principles of Management. Illionis: Richard D. Irwin, Inc. Homewood.

Timpe, A. Dale. (2002). Mengelola Waktu The M anagement of Time, (Alih bahasa Susanto Boedidharmo). Jakarta: PT Elex Media Komputindo.

Tirtarahardja, Umar, dan La Sula. (2000). Pengantar Pendidikan, Jakarta: Rineka Cipta.

Umurohmi, Ulfah. (2007). Kepemimpinan Kepala Sekolah Dalam Pemberdayaan Guru Di Madrasah Mu'allimat Muhammadiyah Yogyakarta. Tesis tidak diterbitkan. Yogyakarta: Program Pasca Sarjana UNY.
Sekretariat Kabinet. (1989). Undang-Undang Republik Indonesia Nomor 2 Tahun 1989 Tentang Pendidikan Nasional, Jakarta: Mendiknas.

(2003). Undang-Undang Republik Indonesia Nomor 20 Tahun 2003 tentang Sistem Pendidikan Nasional, Jakarta: Mendiknas.

Wahab, Abdul Azis. (2008). Anatomi Organisasi dan Kepemimpinan Pendidikan, Bandung: Penerbi Alfabeta.

Widyawati R. Wiwien. (2010). Etika Jawa, Yogyakarta: Pura Pustaka.

Wuradji. (2009). The Educational Leadership: Kepemimpinan Transformasional. Yogyakarta: Gama Media. 